
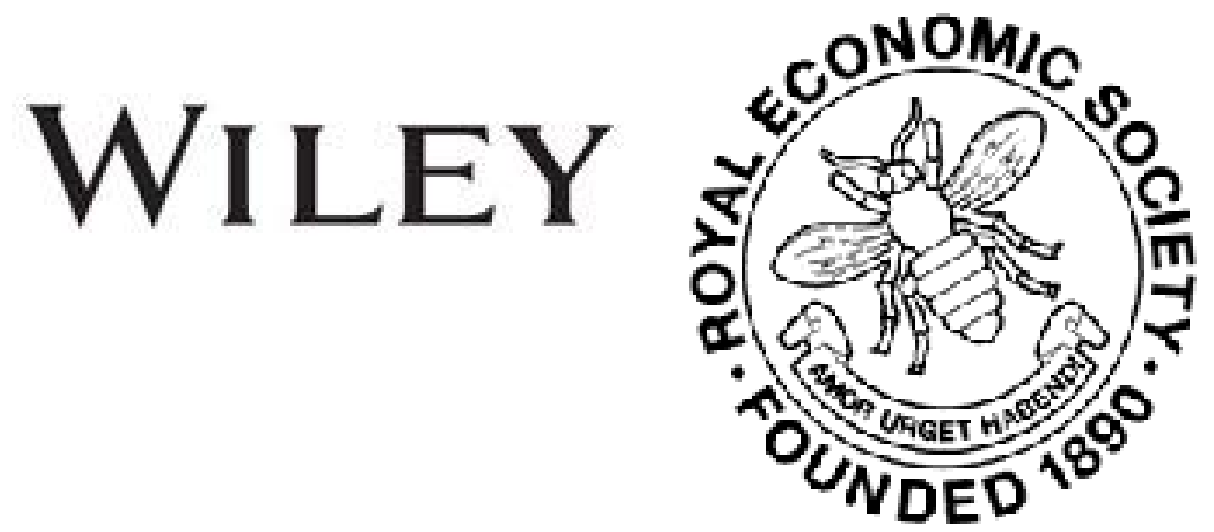

\title{
Adam Smith and His Relations to Recent Economics
}

Author(s): L. L. Price

Source: The Economic Journal, Vol. 3, No. 10 (Jun., 1893), pp. 239-254

Published by: Wiley on behalf of the Royal Economic Society

Stable URL: http://www.jstor.org/stable/2955660

Accessed: 27-06-2016 07:29 UTC

Your use of the JSTOR archive indicates your acceptance of the Terms \& Conditions of Use, available at

http://about.jstor.org/terms

JSTOR is a not-for-profit service that helps scholars, researchers, and students discover, use, and build upon a wide range of content in a trusted digital archive. We use information technology and tools to increase productivity and facilitate new forms of scholarship. For more information about JSTOR, please contact support@jstor.org.

Wiley, Royal Economic Society are collaborating with JSTOR to digitize, preserve and extend access to The Economic Journal 


\section{ADAM SMITH AND HIS RELATIONS TO RECENT ECONOMICS. ${ }^{1}$}

IT is with a feeling of some hesitancy that I submit to the Economic Section of the British Association these fragmentary and inadequate remarks. To say anything new on Adam Smith is not easy; but to say anything of importance or profit, which has not been said before, is well-nigh impossible. I have indeed heard that rumours have been whispered of late in economic circles that he may be more than suspected of the charge so commonly advanced against writers who seem to have made some new contribution to the development of human knowledge, or to have given some fresh exhibition of the fertility of the human imagination, and that, like so many before and after him, he is guilty of plagiarism. It is certainly true that the references to other authors in the Wealth of Nations are comparatively few and far between, that the years, during which the work was in process of composition, were sufficiently numerous to afford time for accumulating a mass of material in common-place books and the like, which may have been included among the papers destroyed, as we know, before Adam Smith's death, that his notorious excellence of memory would have assisted conscious or unconscious appropriation, and that the comparative absence of systematic continuous development through the separate books of his treatise might be held to point to the reproduction of the views of others rather than the formation and statement of his own independent opinions. It is certain that there were economists before him, and he himself is emphatic in his recognition of the merits of his French predecessors; and it is no less certain that he was influenced by the particular circumstances of his time, and that he breathed in the atmosphere of thought by which he was surrounded to an

${ }^{1}$ Read before Section $F$ of the British Association at Edinburgh, August 12, 1892. 
extent which recent historical inquiry and criticism have enabled us to apprehend more fully. But I have neither the wish nor the knowledge to enter on the interesting discussion which these considerations suggest. The determination of the line, where plagiarism ends and originality begins, calls for a fine power of discrimination, and the limits of borrowing without acknowledgment constitute a most delicate and difficult question of literary etiquette. If the ideas, which you are accused of plagiarising, form part of the common stock of the discussions of the day, you may perhaps be allowed to use them without an express recognition of their original ownership. If, in passing them through your mind, you have given them the stamp of your own individuality, it becomes doubtful how far you may claim that they are, in part at least, your own, and how far you are bound to exhibit the precise process by which they have arrived at their present shape. With these nice questions I do not propose to deal, but to attempt the more modest and agreeable task of trying to indicate some of the qualities which have given the Wealth of Nations so high and, as I venture to think, so permanent a place in economic literature. For, explain it as we please, it would be difficult to deny that Adam Smith's great treatise has taken, and retained, a position which is unique. It has become a 'classic.' It has, unlike the mass of economic writing, established itself in the affections of the layman as well as the expert; and, unlike the mass of economic writing also, it has exchanged the fading laurels of ephemeral renown for a crown of abiding glory.

First among its titles to enduring fame I should place the fact that it is a piece of literary workmanship as well as a scientific treatise. I have seen it stated somewhere that Political Economy in its scientific character has suffered from the literary treatment, which it has often received at the hands of practised writers, who wield the effective instrument of a facile pen. This has, so we are told, led to the sacrifice of accuracy of reasoning to finish of expression, and bas permitted sciolists to enter the domains of science. That there is some truth in this argument no one, who knows anything of the history of Economics, would be prepared to deny; and it might perhaps be urged that Adam Smith himself offended against the conditions of scientific exactitude no less than the graces of literary style by his diffuseness and repetition. But it remains true that the Wealth of Nations has a charm in its composition which reveals the literary artist, and that the happiness of many of its phrases has aided the recollection of what would otherwise have been 
speedily forgotten. Literary form is, no doubt, a means to an end, which must not be exalted to an end in Economics more than in any other science; but, despite of all the objections which have been raised, and of drawbacks which it is easy to indicate, there can be no doubt that the layman will concern himself more closely and frequently with it than with most other sciences, and that he will be attracted by grace, and deterred by awkwardness, of composition. If he cannot, and it is surely doubtful whether such a result, if attainable, is really to be desired,-if he cannot be prevented from straying into the preserves of the scientist, it is preferable that he should seek the companionship of the best writers rather than the worst, and it is therefore a matter for congratulation that in Adam Smith he will find a stimulus to thought added to a gratification of taste.

But the attraction of the Wealth of Nations as a literary performance is largely due to the presence of another characteristic, which is held by some critics, and not unreasonably, to militate against scientific exactitude. The exposition of the theory of Economics, we are told, must be carefully distinguished from its application to practice. The theoretical expositor must sternly preserve himself from the dangerous and deteriorating influence of motive or purpose of a practical nature. He must pursue truth and truth alone, turning neither to the right hand nor to the left. Here, again, it would be difficult to deny the force of these arguments, or to ignore the serious mischief which has resulted from the intrusion of partiality or prejudice into the region of scientific inquiry. There can be no doubt that the distinction between the theory of Economics and the art of political or social or philanthropic practice, which has, by dint of constant repetition and urgent insistance, been forced home on the mind of the student, has helped to clarify his views and to save him from hasty unwarranted conclusions. There can be no less doubt that, if the 'man in the street' could be brought to recognise this distinction, the process would be wholesome for himself and for the science which he so often misappropriates to his own ends. But in his case it is almost hopeless to expect to achieve success, and the student, with all his watchfulness, will find the subtle influences of motive and purpose continually trying to reassert their sway and, not infrequently, triumphing over resistance. To look for any other result is to listen to 'counsels of perfection' rather than the plain lessons of common experience. And, whatever may be urged on this point, it is at least certain that in Adam Smith's

No. 10.- -VoL. III. 
time the distinction between the scientific study of the causes, which govern the production and distribution of wealth, and the art of increasing the 'wealth of nations' had not passed beyond its rudimentary stage, if it had even emerged from obscurity at all. And it is no less certain that the persuasive fascination of his writing is largely due to the presence and prominence from beginning to end of his book of one dominant motive and one ruling purpose. It has been said that every page of his treatise is ' illumined' by the 'passion' for freedom, and the most cursory reading of the Wealth of Nations could scarcely fail to disclose this ardent feeling as the most diligent and protracted study would serve but to strengthen the original impression. It is the possession of the whole man by such a passion which renders writers cogent arguers and their readers willing listeners; and, though the passion may, if it is not curbed and bridled, sometimes run away with the judgment, it may also lend a wonderful force to accurate reasoning, and carry conviction to minds unwilling otherwise to listen to wholesome and important truths. As a literary instrument it is unsurpassed; as a weapon of science it is by no means to be lightly esteemed or carelessly dismissed.

This instrument Adam Smith possessed in admirable perfection, and this weapon he wielded with marvellous effect. But it has been said that his passion for freedom was largely a product of the times and an outcome of French speculation in the period before the Revolution; and it has been urged that it led him into an excessive eulogy of the 'obvious and simple system of natural liberty,' which was soon to receive a terrible corrective in the misery and suffering apparently due, to a large extent, to unfettered competition in the early days of the factory system. It has been maintained that, while the removal of the old barriers, which impeded the course of trade, and the shackles, which cramped the movements of industry, was then needed, and was powerfully aided by the strenuous energy and perseverance of Adam Smith, the requirements of later times are different, the extension rather than the limitation of the functions of government, and the enlargement rather than the contraction of the sphere within which the State should regulate or supersede the action of individuals, constitute the pressing need of our day and the most urgent question alike of practical politics and of political theory, and therefore the teaching of Adam Smith is obsolete and the Wealth of Nations has no message for us. But, on the other hand, it has been pointed out that Adam Smith himself was too shrewd an observer of human nature, and too keen a 
judge of the exigencies of practical affairs, to believe in uncontrolled individualism or, as it has been happily called, 'administrative nihilism;' and he recognised that there was a sphere for State action, and departments of life where its absence would be fraught with social injury and danger of the gravest kind. The question is often stated as if the choice lay between no interference on the part of the State and complete arrangement and control; but it is really a question of degree, and in this lies its difficulty. Adam Smith, no doubt, inclined to the less rather than the more; we perhaps have latterly been disposed to go some way in the opposite direction. But he would be a bold man who would deny that the crying need of the days of the Wealth of Nations was the limitation of State meddling, and the removal of multitudinous restrictions and narrow exclusive regulations. Nor would it argue less ignorance of human nature, or less unintelligent acquaintance with the movement of affairs, to dispute the pertinence to all time of much that Adam Smith urges in defence of liberty. Attacks upon freedom are the melancholy feature of more than one condition of society and of more than a single epoch in the world's history. The argument in favour of liberty may be pressed too far, and Adam Smith may have fallen into this error; but it is rarely inopportune, and it is seldom, if ever, superfluous. Liberty is assailed in so many and such subtle forms that the claims of its champions have a perennial application; and, when the advocacy of freedom means, as in Adam Smith's case, the pleading of the cause of the weak oppressed by the strong, and the vindication of the rights of the defenceless, it is premature, as it is ungracious, to say that he has no message for our time. His passion for liberty, which illuminates all his pages, sheds its lustre over the problems of this and every age; and it gives a permanent value as well as imparts a persuasive charm to the Wealth of Nations.

Adam Smith's merits do not appeal to the lover of the interesting alone. In fact the number of minds, which have agreed, while differing on other subjects, to unite in praising the Wealth of Nations, is not the least remarkable or conspicuous testimony to its unique character. We have already observed that it appeals, and appeals successfully, to the layman as well as the expert; and statesmen and men of affairs, from Pitt downwards, have derived instruction, and obtained guidance, from its pages no less than academic economists. The causes of this wide popularity are not far to seek. The 
language of Adam Smith is admirably simple and clear, his reasoning direct and forcible to a degree unsurpassed, and perhaps unapproached, by other writers on a subject which it is only too easy to make repellent and difficult, and his illustrations are at once abundant and apt. The strong motive, by which his argument is informed, gives an air of unmistakable reality to his writing, and he always seems to be in the closest touch with actual present fact. These are the very qualities to appeal to the plain practical man ; but the remarkable characteristic of Adam Smith is that he appeals with equal strength to the trained economist. The position of the Wealth of Nations in strictly economic literature is as unique as is the fact that it occupies a recognised place among the classic productions of men of letters of all times. The comparative simplicity of economic theory in Adam Smith's day, as contrasted with the more elaborate and complex development of later periods of thought, might have been expected to render the Wealth of Nations attractive to the outsider, deterred by the terms and formulæ of more specialised, but exact, knowledge and inquiry; but for this very reason the professed economist might have been supposed to be likely to regard the book as interesting rather as evidence of what Economics had been in a comparatively unadvanced stage, and as an example of the early form which doctrines, developed since, had then assumed. But he might not improbably have thought that its antiquarian interest was its strongest point, and that later reasoning had superseded it as an engine for inquiry and speculation. Such a conclusion would, no doubt, be natural ; and chapters in Adam Smith might be cited in its support. The importance which, in spite of his criticism of the system of the Physiocrats, he assigned to agriculture, in which, he said, ' nature laboured along with man,' and the order in which he ranged the employments of capital in the same chapter, ${ }^{1}$ very suggestive as it is in the light it throws on his mental environment, but containing also not a little which would now be stated differently, if it were not regarded as obsolete, are examples of this. But the surprising fact remains how little is really unimportant now, and how much is supplied in germ in the Wealth of Nations, which later investigation has done no more than develop into the maturer plant. Few, if any, writers on a subject, which has to deal with the changing phenomena of human society, could stand so well the test of a hundred years of study and criticism, or, after the lapse of so long a time, appear so fresh and apposite.

${ }^{1}$ Book II. Chapter V. 
To this point I propose to return later; what I wish now to emphasise is the way in which by writers of almost every school, in England at least, Adam Smith has been regarded as the parent of modern Economics. It is true that recent research has called attention to the important contributions of authors before his time, who had been over-shadowed by his fame and greatness; and the Wealth of Nations was no more the end than it was the beginning of economic study. But throughout the subsequent history of Economics, at any rate in this country, there has been one writer and one treatise to which all others have in turn traced the origin of most of their ideas; and that writer has borne the name of Adam Smith, and that treatise the title of the Wealth of Nations. Even in the generation which immediately followed its issue, it seemed as if in the persons of Malthus and Ricardo Political Economy would break up into two opposite schools of thought pursuing two different methods of inquiry. Certain it is that many of the fundamental issues raised in later controversy were started at that time; and the Letters of Ricardo to Malthus may from this point of view be read even now with interest, although they refer in many instances to passing practical questions of the day. And yet Malthus and Ricardo, in spite of their fundamental differences, owned Adam Smith to be their common teacher, although, like able pupils, they were not afraid to criticise, and improve on, their master.

The same feature has repeated itself through the course of subsequent discussion. In Germany, no doubt, Smithianismus has become a term of reproach, and the ghost, conjured up under this name, has been assailed with all the weapons which painstaking research, and wide erudition, and enthusiastic zeal for a new creed, could command; and the attack, perhaps we may add, has after all been eluded owing to the unsubstantial and imaginary character of the object of assault. But, if we turn to the representative of the German historical school, who in recent times has led the onslaught in England, we find that, while he criticises Adam Smith with perfect freedom, and shows how he was influenced by the facts and thought peculiar to his time, he places him on quite a different level from Ricardo, and claims the Wealth of Nations as a brilliant illustration of the advantages of the inductive as opposed to the deductive method of inquiry. In one of the most interesting of his essays, ${ }^{1}$ Cliffe Leslie observes that the followers of the orthodox school now reply to their

${ }^{1}$ Political Economy and Sociology. 
opponents by a cry 'of the greatness of Adam Smith.' 'And,' he adds, "it is well that the cry is now for him instead of Ricardo.' But, he proceeds later, ' it reminds one of the contest between the spirits of darkness and light for the body of Moses to find the followers of Ricardo claiming Adam Smith for their prophet.' "Whom ye ignorantly worship, him declare I unto you," the true disciple of Adam Smith may say to those who raise altars to his name, but to whom he is virtually an unknown being.' And he goes on to argue that the method employed by Adam Smith was inductive, and to illustrate this point in particular by the 'famous tenth chapter of his first book.' 'The notion of evolving from his own consciousness the circumstances and motives that diversify the employments of a nation, and the remuneration obtained in them, would be preposterous, even if Adam Smith himself had not expressly stated at the beginning of the chapter that he had gathered them from observation.' Cliffe Leslie's opinion is entitled to great respect, for the influence which his writings have exercised on the conception of method, and the development of theory, has been considerable; but it is curious to turn from his assertions to the conclusions drawn by other writers.

For what does the author of the most recent English treatise on economic theory say? Professor Marshall is even more emphatic than Cliffe Leslie in his praise of the Wealth of Nations. 'The next great step in advance, the greatest step that economics has ever taken, was the work,' he declares, ${ }^{1}$ ' not of a school, but of an individual.' 'Wherever' Adam Smith 'differs from his predecessors, he is more nearly right than they; while there is scarcely any economic truth now known of which he did not get some glimpse.' And what are the grounds on which Professor Marshall bases this ungrudging eulogy? 'His chief work,' he observes, "was to combine and develop the speculations of his French and English contemporaries and predecessors as to value. His highest claim to have made an epoch in thought is that he was the first to make a careful and scientific inquiry into the manner in which value measures human motive, on the one side measuring the desire of purchasers to obtain wealth, and on the other the efforts and sacrifices undergone by its producers.' The work, however, thus described is largely deductive as well as inductive, and at any rate it places Adam Smith in the direct line of descent to Ricardo and the so-called abstract school. It is opposed to Cliffe Leslie's verdict, as it is more compre1 Principles of Economics, Vol. I., Book I., Chapter IV., Section 3. 
hensive; and Professor Marshall proceeds to remark that the Wealth of Nations, "though not well arranged, is a model of method; for' Adam Smith 'saw clearly that while economic science must be based on a study of facts, the facts are so complex, that they generally can teach nothing directly; they must be interpreted by careful reasoning and analysis. And, as Hume said, the Wealth of Nations " is so much illustrated with curious facts that it must take the public attention." This is exactly what Adam Smith did; he seldom attempted to prove anything by detailed induction or history. The data of his proofs were chiefly facts that were within every one's knowledge, facts physical, mental, and moral. But he illustrated his proofs by curious and instructive facts; he thus gave them life and force, and made his readers feel that they were dealing with problems of the real world, and not with abstractions.'

Discussions on method are perhaps never very profitable, and Economics has had more than its full share of such discussions. I do not propose to enter now on the treatment of the questions, interesting though they may be, whether Adam Smith reasoned in the main inductively or deductively, and whether he more generally constructed his theory from observation of collected fact or used his facts to verify and illustrate his theory. It is hard to draw a rigid line between deduction and induction, and to say where the province of the one ends and that of the other begins. It is now generally allowed that Economics may and, if it is to advance, must avail itself of all the aids to inquiry and speculation which the wit of man has discovered. It must use in turn, as the circumstances favour, induction, deduction, observation, experiment, hypothesis, and verification. Later investigation has, no doubt, emphasised the importance of facts, but it has not lessened the advantage of employing the instrument of method in all its varieties and patterns to handle facts. And so it seems probable that Adam Smith, like other writers, sometimes used what would probably be called an inductive, and sometimes what would be broadly distinguished as a deductive method, that sometimes he constructed his theory from his facts, and sometimes he employed his facts to verify and illustrate his theory. That it should be, as it still is, a disputed question whether the one or the other form of reasoning predominated in his treatise is a testimony to the catholicity of his work; that he should be labelled now deductive, and now inductive, may not unreasonably be held to point to the conclusion that he was not exclusively either, but embraced elements 
of both. And, whatever may be said as to the method he employed, it is certainly remarkable that he should be highly esteemed alike by what we may perhaps without offence call historical dissenters and orthodox believers, and that the germs of the 'theory of measurable motives,' as well as illustrations of the systematic knowledge slowly built on the observation of a mass of facts, should be discovered in the Wealth of Nations. In this respect it is surely unique in economic literature.

Nor does the theorist find in its pages merely the rudiments of the central theory of Economics, but, if he examines the different departments of the science, he is astonished to discover how close Adam Smith is to the latest results of economic inquiry. There is, it is true, no formal or regular division in the Wealth of Nations into separate departments dealing with production, distribution, exchange and consumption; and the arrangement of the treatise is lacking in system. But the early treatment given to exchange as arising naturally from division of labour, and facilitated by the use of money, the tool of exchange, the prominence assigned to value as the dominant fact in exchange, the distinction drawn between natural and market value, and then the manner in which, after substituting the consideration of price for that of value, and noticing demand, the natural price is resolved into the elements of which it usually consists, and the wages of labour, the profits of stock, and their differences from occupation to occupation, whether due to artificial or natural causes, and the rent of land, are succesively considered, are in accordance with the general tenour of recent investigation; and the first two books of the Wealth of Nations may be said to contain a theory of production, exchange and distribution, which presents in essence the fuller development of later criticism and speculation.

If we take, for instance, the laws governing the earnings of the different classes of participators in the distribution of wealth, it is truly surprising to find how successfully Adam Smith seems to have avoided many of the errors of subsequent thinkers, as they now appear, and to have seized hold of the essential elements of the truth. It appears tolerably certain that he did not fall into the characteristic fallacies of the wage-fund theory, although he speaks of the 'funds' from which wages might be paid, and he seems to have grasped the notion of a lower limit to wages in the standard of comfort of the labourer, and an upper limit in the wealth of ar nation, between which the market forces might operate. On the subject of profits he writes with a domestic system of industry 
before his eyes, where there was little scope for the work of management, as compared with the huge industrial and commercial undertakings of the present day. And so he uses the term profits to denote the interest of capital, varying, as he says, entirely according to the amount of the stock employed; and he will not allow the element of wages of management to come into prominence. In the case of the 'apothecary' and the 'village grocer' he expressly brings under the category of wages, and excludes from the class of profits, what we should now term earnings of management. The American economist General Walker has, on the other hand, employed the term profits to denote these wages of management exclusively, and separated the interest of capital' from it, and, in doing so, he has marked the change which has taken place in the organisation of industry. But the common English use of the term embraces both elements, and Adam Smith is in accord with the most recent tendency of economic speculation to consider under one and the same general head the wages of management and the wages of labour, and to regard as similar the general laws governing the earnings of all descriptions of labour,-whether that of direction or that of obeying direction. On the matter of rent there are reasons for doubting whether he fully grasped, or consistently held, the theory known as the Ricardian theory, but he went some way towards doing so, and his statement that the rent of land ' not only varies with its fertility, whatever be its produce, but with its situation, whatever be its fertility' has the merit of stating concisely, and yet explicitly, what Ricardo mentioned but allowed many of his readers to forget.

So far for Adam Smith's treatment of distribution ; and, before we pass to the later books of his treatise, it may be asked whether the advantages and dangers of paper money have ever since been more pithily expressed than in his remark that 'the gold and silver money which circulates in any country may very properly be compared to a highway, which, while it circulates and carries to market all the grass and corn of the country, produces itself not a single pile of either. The judicious operations of banking, by providing, if I may be allowed so violent a metaphor, a sort of waggon-way through the air, enable the country to convert, as it were, a great part of its highways into good pastures and cornfields, and thereby to increase very considerably the annual produce of its land and labour. The commerce and industry of the country, however, it must be acknowledged, though they may be somewhat augmented, cannot be altogether so secure, when they are thus, as it were, suspended upon the Dædalian wings of paper 
money, as when they travel about upon the solid ground of gold and silver.' The temptation to quote from the Wealth of Nations is very powerful, and may easily become irresistible; but I have not time to make, and you would scarcely have patience to listen to, more on the present occasion. The quotation, which I have just made, seems to me to afford so perfect an example of the qualities, which have contributed to give Adam Smith's treatise its high position, that I could not forbear to cite it. We see in it that power of direct and lucid statement, that facility of expressing in a sentence a profound and far-reaching truth, that felicity of apt illustration, which render the book at once so pleasant and so valuable. Adam Smith is sometimes diffuse, but he can also be remarkably terse, and he has the rare merit of luminous exposition and of relieving the tedium of dry reasoning by interesting and appropriate illustration. His wide acquaintance with fact, and his strong sense of its importance, combine with his extensive knowledge of the learning, with which the educated minds of his age were furnished, to enable him to employ within the compass of a paragraph a homely metaphor, which he may call 'violent' but his readers deem as suitable as it well can be, and also a parallel, just as apt but as classical as the metaphor is drawn from the common knowledge of the average man.

But we are returning to the consideration of the literary side of the Wealth of Nations; and, with a repetition of the opinion that it is only too possible to underrate the value, even for scientific ends, of literary excellence, and a mere passing allusion to the admitted belief of economists of different schools that Adam Smith's treatment of the division of labour, of the origin and use of money, of the rules and maxims of taxation, has perhaps been added to and improved, but has not been superseded, by later inquiry, we must press on to the consideration of that part of the book which has been most generally associated with the name of its author, and has achieved the most remarkable success in the domain of practical affairs.

Adam Smith's examination of the Mercantile System has been critically reviewed by writers of great ability and learning. Historians have shown that the Mercantilist views were more reasonable than the reader of the fourth book of the Wealth of Nations might suppose, and that they were actually in keeping with the practical exigencies of the times in which they were advanced. Able Protectionists have opposed to Adam Smith's undoubted cosmopolitanism a National System, and no fairminded student can read List, for example, without recognising 
his persuasiveness and the force of some of the arguments he uses in reply to Adam Smith. Economic theorists, who believe in Free Trade, or at any rate in Free Trade for England, have brought into the light possibilities of which Adam Smith did not take full account: and the encouragement of 'infant industries' by Protection, to be withdrawn when they are able to stand by themselves and have attained maturity, has been allowed an economic justification by writers of the rank of Mill, who shocked some of his admirers by his candid admission. But those writers have been careful in most cases to add that the selection of the 'infants' to be specially nurtured requires an extraordinarily impartial and prudent government, and the removal of the protection, when it is no longer needed, calls for a remarkably strong and discreet administration. The economic basis of the argument is sound, but the political foundation is weak and shifting. Again, the difference between a country whose commodities obey a law of increasing returns, and one whose commodities are governed by a law of diminishing returns, as exchanging parties, has by recent writers been applied to the theoretical question of Free Trade and Protection, and some economic defence discovered for opinions and acts of a seemingly heretical character. Nor can it be denied that the tariff policy of so many European States, of the great American Republic, and of our own colonies, although in the first case the eminent desirability of raising a large revenue for military purposes by the easy, imperceptible, and indirect means of taxation of imported commodities, in the second the immense area-perhaps the largest of its kind-of the United States, throughout which complete freedom of trade prevails, and the comparative unimportance of the question, and in the third the revenue considerations, which render direct taxation so difficult and expensive in a comparatively new country, might be advanced in explanation-it cannot be denied that this tariff policy has shaken the hopes raised by the more liberal movement of tariffs some little while ago.

But, with all these adverse influences, it is still surprising to find how fresh and forcible is the reasoning of Adam Smith's fourth book, and with how sure an instinct he seized on the most important and enduring arguments. There are two main grounds on which he may be said explicity to base his contentions, and a third is implicitly contained in his language. The first of these arguments is the justice and advantage of freedom. Every individual, he maintains, in his own place and station can judge of the proper employment of his capital better than a lawgiver 
or government can do for him. It would be difficult to deny the force of this argument, though the further conclusion which he draws, that the consideration of a man's own interests will lead him to promote the interests of the community, might now be received with some qualification. But the general drift of the argument in favour of individual freedom in the employment of capital is admittedly very powerful. Connected with this is the argument, implied rather than stated, that there is a division of labour between nations as between individuals; that similar advantages result from its institution in encouraging production and developing capacities; and that, as domestic division of labour implies, and follows on, freedom of exchange, so the necessary condition of territorial or international division of labour is Free Trade.

But after all neither of these two arguments, though they are forcibly urged and aptly illustrated, seems to be that to which he is inclined to give the greatest prominence. It is the erroneous conception of money in the Mercantilist doctrine to which he devotes most continual attention, and it is on the correct idea of its functions and place in industry and commerce that he lays repeated insistance. No doubt this emphasis was naturally suggested by the arguments of the advocates of the Mercantile System, to whom he was specially replying, but it seems also, in a higher degree than the other arguments which he advances, to give an enduring application to his reasoning. The conception that trade is an exchange of goods for goods in international as well as in domestic transactions is a touchstone to which protectionist arguments may be brought with, as an almost invariable rule, serious, if not fatal, consequences to their validity. The fact that a nation pays for its imports by its exports is one which it is hard, if not impossible, to contest, if it is once apprehended; but there are few protectionist reasonings which can successfully confront it. That the process might be circuitous and indirect Adam Smith freely admitted; and the circuit has extended, and the accomplishment of its passage taken a longer time, since he wrote. The 'invisible exports,' as they have been called, of the capital and labour engaged in our shipping industry in carrying goods from one country to another, and the interest due on our investments abroad, have grown in volume since the publication of the Wealth of Nations. That gold and silver might form part of those imports and exports Adam Smith unhesitatingly allowed; but that they formed a small and insignificant part he stoutly maintained, and that the transit of bullion was avoided 
as far as possible he strenuously affirmed. Nor, in the case of countries like Great Britain, which did not themselves produce the precious metals to any large extent, could they be procured in the first instance except by the exchange of goods. These arguments have not lost their validity or pertinence, and any one acquainted with the difficult theory and complex practice of the foreign exchanges will remember that they turn on the anxiety to avoid the transit of bullion, while the growth of credit and its use in international trade have diminished the proportion of that trade effected by the passage of money to an extraordinary extent. And yet it is scarcely possible to read a protectionist pamphlet, however able and well-informed, without finding the old mistakes about money making their reappearance in some cunning disguise. It is as true now as it was when Adam Smith wrote it that 'even they who are convinced' of the 'absurdity' ' that wealth consists in money, or in gold and silver,' 'are very apt to forget their own principles, and, in the course of their reasonings, to take it for granted as a certain and undeniable truth.' Nor is it less true that ' writers upon commerce set out with observing that the wealth of a country consists, not in its gold and silver only, but in its lands, houses, and consumable goods of all different kinds. In the course of their reasonings, however, the lands, houses, and consumable goods, seem to slip out of their memory; and the strain of their argument frequently supposes that all wealth consists in gold and silver, and that to multiply those metals is the great object of national industry and commerce.'

Adam Smith never anticipated the 'complete restoration' of freedom of trade in Great Britain; and, had he lived to see this result accomplished, his disappointment as a mistaken prophet might have mingled with his satisfaction as a convincing reasoner. Few triumphs of a higher kind have ever been achieved by a speculative philosopher in the region of practical affairs ; for, while it was the stern logic of fact, enforced by the famine in Ireland, which brought about the repealof the Corn Laws, some of the most persuasive arguments used by Cobden on the platform reflected the spirit, if they did not reproduce the language, of the Wealth of Nations; and certainly Cobden himself and the succession of reforming finance ministers from Pitt, who showed that, had he enjoyed the opportunity, he would have anticipated the liberalising measures of later times, to Mr. Gladstone, who put the crowning touches on a purified tariff, would have been proud to own that they were pupils of the 
Glasgow professor. It might, indeed, have been well, had it been possible, if the common people had learnt their lesson also from the book and not from the facts. Facts may be forgotten when they have passed away, but 'litera scripta manet,' and it almost seems as if before long the battle may have to be fought over again.

May I add one word in conclusion, and that is simply to express the pleasure of being permitted as an Oxonian to do honour to the memory of Adam Smith in this famous and beautiful city, where he first lectured and established a reputation, where he formed that intimate friendship with David Hume which endured throughout life, and where he spent the greater part of his closing years and, dying in the ripeness of age and honour, was laid in his last resting-place? If Oxford treated Adam Smith ill as a student in her unregenerate days, she, in common with the World, accords him a high place on the roll of the World's worthies, and she is proud to number him among the most distinguished of her own sons. But it is to Scotland that Adam Smith owed most, and it is to Scotland also that students of Economics are in duty bound to express their gratitude for having given birth to the bearer of the greatest and most honoured name in the annals of this branch of learning.

L. L. PRICE 